\title{
Tourism planning in the Azores and feedback from visitors
}

\author{
Planeamento turístico nos Açores e feedback dos visitantes
}

\author{
João Ponte
}

Fundo de Maneio, Ponta Delgada, Portugal, jcrispim@fundodemaneio.com

\section{Gualter Couto}

School of Business and Economics and CEEApIA, University of the Azores, Portugal, gualter.mm.couto@uac.pt

\section{Pedro Pimentel}

School of Business and Economics and CEEApIA, University of the Azores, Portugal, pedro.ms.pimentel@uac.pt

\author{
Áurea Sousa \\ School of Sciences and Technology and CEEApIA, University of the Azores, Portugal, aurea.st.sousa@uac.pt
}

\author{
André Oliveira \\ Fundo de Maneio, Portugal, aoliveira@fundodemaneio.com
}

Received: 19.09.2020; Revisions required: 12.12.2020; Accepted: 14.03.2021

\begin{abstract}
Tourism planning is increasingly a fundamental process for qualifying and increasing the competitiveness of tourist destinations, especially when it is required to take into account the new needs of tourists and the global trend towards meeting the principles of sustainable tourism. This study aims to analyse the improvements that, in the opinion of visitors, should be implemented in Ponta Delgada, the largest hub of tourism activity in the Azores (Portugal), detecting differences between specific groups of visitors in order to contribute to the territorial organisation and the optimisation of tourism experiences. Four hundred answers to a survey distributed among tourists who visited this Azorean municipality were analysed, using several statistical methods, such as the chi-square test of independence and some Hierarchical Cluster Analysis algorithms. The main conclusions refer to the statistically significant associations between the mean of transport used to travel and views of some aspects to be improved, with signs of patterns in visits and critical attitude.
\end{abstract}

Keywords: Tourism planning, surveys, tourist experiences, tourism competitiveness.

\section{Resumo}

O planeamento turístico é cada vez mais um processo fundamental para a qualificação e aumento de competitividade dos destinos turísticos, principalmente quando há que ter em conta as novas necessidades dos turistas e a tendência global de atender aos princípios do turismo sustentável. Este estudo pretende analisar as melhorias que, na opinião dos visitantes, devem ser implementadas em Ponta Delgada, o maior polo dinamizador da atividade turística dos Açores, contribuindo, assim, para a organização territorial e para a valorização das experiências turísticas. Foram analisadas as respostas de 400 questionários administrados a turistas que visitaram este concelho, utilizando diversos métodos estatísticos, de onde se destacam o teste de independência do quiquadrado e alguns algoritmos de Análise Classificatória Hierárquica Ascendente. As principais conclusões referem-se à existência de associações estatisticamente significativas entre o meio de transporte utilizado para viajar e as perceções acerca de alguns aspetos que podem ser melhorados.

Palavras-chave: planeamento turístico; questionários; experiências turísticas; competitividade turística.

\section{Introduction}

Nature is one of the main tourist attractions in the Azores, linked to the region's cultural expressions and typical traditions (Couto, Pimentel \& Ponte, 2017; Couto et al., 2020). Time and again, this archipelago, made up of nine islands with their own identity and an extraordinary natural legacy (Vieira et al., 2013), is highlighted as one of the most sustainable destinations in the world. It is the only destination in the world to have received the Platinum Quality Coast Award twice and has also been in Green Destinations' Top 100 Sustainable Destinations since 2014. In order to give the region a competitive advantage with clear benefits for tourists and residents, the destination's management bodies have based tourism development on sustainability. In line with this, a process was implemented to certify the Azores under the criteria of the Global Sustainable Tourism Council, resulting in a unique certification at the level of archipelagic destinations.
Tourists' perceptions on the various aspects of a region (e.g., the quality-price ratio of accommodation, restaurants, entertainment, availability and quality of information, services, tourist attractions, among other aspects) can promote or downgrade the image of a tourist destination, with substantial impacts on the competitiveness of the destination (Silva, 2017). Improving the tourist offer, with added value, by investing in improving the quality of services, preserving heritage (natural, cultural, gastronomic and built) and implementing activities that aim to provide good and exciting experiences for tourists to enjoy, remember fondly and recommend to friends and family, is essential, in the context of tourist development that advocates for the environmental, economic and socio-cultural sustainability of the Azores as a tourist destination (Ponte, Couto, Pimentel, Sousa \& Oliveira, 2020).

It is clear that tourism planning, regionally, as well as at municipal and local levels, will have to consider a strict balance 
between the critical factors that ensure sustainability in all these areas (Silva, 2017). One of these factors is the needs of tourists, which are continually mutating along with technological and socio-cultural development. Therefore, understanding the type of tourist who visits the Azores is key to increasing the competitiveness of this destination, and that will have to be taken into account in the strategic planning of the territory (Couto et al., 2017; Ponte, Couto, Pimentel, Sousa \& Oliveira, 2019).

This study aims to assess the main aspects that, in the opinion of tourists, should be improved or implemented in the municipality of Ponta Delgada, to promote quality improvements and the enhancement of this tourist destination, which is the largest urban centre of the Azores archipelago and the main hub for tourism and other economic activities (Couto, Pimentel, Santos, Ponte \& Oliveira, 2018). It also aims to detect groups of items related to different aspects, for which the respondents' responses were similar concerning the need for improvement or implementation. Another objective was to compare the views of visitors who travelled by boat (Cruise ship/Yacht) with those of visitors who travelled by aeroplane in relation to aspects to be improved or implemented in the municipality of Ponta Delgada.

Section 2 lists the main aspects to be taken into consideration within the scope of sustainable tourism planning. Section 3 presents the main methodological procedures and the variables of the study. Section 4 summarises the main research findings. Finally, Section 5 makes a few final considerations on the results obtained and their possible implications for the development of public policies aimed at promoting the Azores as a tourist destination.

\section{Literature review}

McMinn (1997) notes that the concept of 'sustainable tourism' emerged soon after the concept of sustainable development and that, to become sustainable, tourism must bring economic advantages, create social benefits for local communities and not harm the environment, while ensuring its application to the present and the future. Moniz (2009) adds that the concept of sustainability in the context of tourism is vast and complex and can take on different meanings depending on the stakeholders involved. The author states that the definition of sustainable tourism is inherently subjective and multidimensional and that sustainable tourism activity is that which:

i. Provides a quality experience to visitors, simultaneously contributing to improving the quality of life of local populations and protecting the quality of the environment;

ii. Provides a satisfactory experience for visitors whilst ensuring the continuity of natural resources and that is based on the cultural identity of the host community;

iii. Allows for a balance to be struck between the needs of the sector's players, the protection and needs of the environment and the needs of the local population; iv. Emphasises the defence of common interests and cooperation between visitors, the local community and the destination.

Buhalis (2000) stresses that probably the greatest challenge lies in ensuring the rational use of public assets that do not have an economic valuation, such as landscapes, mountains and the sea, so as to benefit all the stakeholders of a tourist destination while preserving resources for future generations. Briassoulis (2002) also reflects on the consumption of common goods through tourism activity, noting that the economic well-being of host communities, although often improved in the early stages, is not promoted when overuse of resources generates direct and indirect monetary costs (e.g., reduced revenue and lack of job opportunities). Conversely, under-utilisation or abandonment of structures creates economic inefficiencies and long-term environmental impacts. Either situation leads to irreversible environmental damage, reducing the attractiveness and competitiveness of destinations.

In this sense, Dinica (2009) states that the development of tourist destinations and products should avoid negative impacts on resources while continuing to attract visitors, contributing to the sustainable development of the sector at a national level. McMinn (1997) argues that, by preserving or improving local environmental features, we are helping the development of local tourism and ensuring its longevity, naturally with economic benefits. Additionally, Mihalič (2000) reinforces the notion that the environmental quality of a destination is a key factor in travel decision making, as well as a competitive factor among different tourist destinations with varying environmental qualities. On the other hand, tourists' demands for more environmentally friendly tourism practices and destinations should be taken into account (Veiga, Santos, Águas \& Santos, 2018). In this sense, Buhalis (2000) recalls that, before visiting a place, tourists develop a mental image of the destination and create a set of expectations based on previous experiences, word-of-mouth, press articles, publicity and general knowledge. They thus portray a destination as a 'brand' that comprises a multiplicity of elements that must be maintained and preserved in order to meet the wishes and expectations of the consumer. That is why this researcher argues that local resources are the central assets of a destination and that tourism agents and their sustainability are a central function of tourism marketing. He also points out that during their stay, tourists 'consume' a destination as an integrated experience, often without realising that each element of this 'product' is produced and managed by individual agents, who have different interests and goals and who interact differently with local resources.

Buhalis (2000) showed that each destination experiences different socio-cultural impacts during the various development stages of its life cycle, resulting in the need to use strategic planning and marketing processes to encourage sustainable practices for consumers and the industry as a whole, as well as to communicate environmental and socio- 
cultural policies. In turn, Briassoulis (2002) observes that the lack of territorial planning and the inability to strategically guide tourism development have irreversible impacts on the competitiveness and sustainability of destinations since decisions with impacts on the environment can lead to a decline in the natural capital of a given area, making it less selfsufficient and attractive.

However, it is interesting to note that Jackman, Lord, Lowe and Alleyne (2011) conclude that, in seeking to foster the sustainable development of the tourism industry, policymakers in Small Island Developing States (SIDS) have focused on increasing their competitiveness. Despite some improvements, none of these countries has been able to consolidate a clear comparative advantage. This is why these authors defend the need to raise the quality and planning of tourism products, thus enhancing the competitiveness of the destination and the sustainability of tourism activity. In this context, Romero, Mastronardi, Tarelli and Haslop (2019) demonstrate the difficulties that can arise from a lack of data and up-to-date information, although they also state that there are ways to avoid these situations. Ponte, Couto, Pimentel and Oliveira (2018) also explore the typical profile of tourist entertainment companies on small islands, which show signs of potential competitive difficulties.

For Sukiman, Omar, Muhibudin, Yussof and Mohamed (2013), the failure to deliver expected quality leads to poor performance in the tourism industry. As such, gathering information about tourists' expectations of the destination is very important in order to know the dynamics of the target market's needs, as well as to potentially increase the competitiveness and performance of tourist destinations. Additionally, to emphasise that consumer satisfaction reflects the quality of service, the authors state that motivation to travel to a specific region has impacts on satisfaction since motivation generated by individual needs and/or values is the most significant parameter in shaping expectations and perceiving performance.

Tseng (2012) says consumer satisfaction with different travel services has been a valuable concept in understanding the strengths and weaknesses of a given tourist destination. The author uses literature to remind us that high levels of tourist satisfaction can encourage tourists to return - which, even if it is a trip with another purpose or with consumption of other tourist products, is the repeated consumption of a destination - and positive word-of-mouth, a key element for the success of any business. In parallel, Hui, Wan and Ho (2007) state that keeping existing consumers has a lower associated cost than winning over new customers. This type of rationale has been used, for example, in the structuring of nature tourism products, where the needs (and perspectives/expectations) of tourists are fundamental (Fossgard \& Fredman, 2019), sometimes leading companies to specialise in their activities (Ponte et al., 2018).
Philips and Moutinho (2014) stress that strategic planning in tourism is key, as it allows to shape competitive benefits in taking advantage of new opportunities and to provide direction to the destination's various stakeholders. Silva and Almeida (2013) reinforce this idea, mentioning that the new paradigms and the increase in demand and competition increase the need to invest in effective planning and management processes. In fact, tourism is a sector where quality plays a crucial role, as destinations are constantly compared with each other, as a result of the globalisation process that has increased competition among them worldwide (Santos, Couto, Pimentel \& Vieira, 2011). A study conducted by Benckendorff and Pearce (2003) suggests that attractions with high levels of planning tend to have higher levels of perceived performance and to be more profitable organisations. Mihalič (2000) stresses that a well-structured destination management programme can serve to increase tourism competitiveness and recalls that there is convincing evidence that visitors steer clear of destinations they consider to be polluted.

Indeed, with companies, regions and countries investing in quality as a competitive advantage (Santos et al., 2011), the lack of an adequate strategic planning process will ultimately lead tourist destinations to failure and the inability to seize market opportunities. Kozak and Baloglu (2011) believe that the future competitiveness of tourist destinations will be directly related to their concern for sustainability. Several initiatives by small destinations, including the Azores, reflect this, namely through strategic planning of tourism activity (Romero et al., 2019; Ponte et al., 2020).

\section{Method}

The objectives of this work are to identify specific factors that need to be improved or implemented in order to enhance the value of the Ponta Delgada municipality as a tourist destination and thus increase its competitiveness and the competitiveness of the Autonomous Region of the Azores as a whole (Couto et al., 2018). To this end, a questionnaire survey was conducted on a sample of tourists in this municipality in August and September 2016. The questionnaires were carried out in Ponta Delgada's historic centre and cruise terminal, as well as in the main tourist spots of the island of São Miguel, including Sete Cidades, Lagoa do Fogo and Furnas (some of the other tourist spots were selected at random from a list of possible tourist spots (clusters), as in a clustering sampling). The municipality of Ponta Delgada concentrates about $80 \%$ of the tourist demand of the island (i.e., number of guests in tourist accommodation) and has its only two entry points (airport and cruise terminal). This justifies the application of the survey elsewhere on the island, outside the municipality of Ponta Delgada. It should also be noted that the surveys were carried out in person, with each tourist filling out their own individual form, after a brief explanation by the person in charge and once they had consented to take part. 
Ponte, J., Couto, G., Pimentel, P., Sousa, Á., \& Oliveira, A. (2021). Tourism \& Management Studies, 17(2), 7-15

Table 1 - Sociodemographic characteristics of respondents (\%)

\begin{tabular}{|c|c|c|c|c|c|c|c|c|c|c|c|c|}
\hline \multicolumn{2}{|c|}{ Gender } & \multicolumn{3}{|c|}{ Age } & \multicolumn{3}{|c|}{ Means of transport } & \multicolumn{2}{|c|}{ Country } & \multicolumn{3}{|c|}{$\mathbf{1}^{\text {st }}$ time in the Azores } \\
\hline Male & Female & $<=34$ & $35-54$ & $>=55$ & Boat & Aer & & Portugal & Abroad & Yes & No & \\
\hline 60.0 & 40.0 & 26.1 & 40.2 & 33.7 & 50.5 & & & 18.8 & 81.2 & 68.1 & & 31.9 \\
\hline \multicolumn{10}{|c|}{ Employment status } & \multicolumn{3}{|c|}{ Reason for travel } \\
\hline \multicolumn{2}{|c|}{ Self-employed } & \multicolumn{2}{|c|}{ Employed } & Retired & \multicolumn{2}{|c|}{ Student } & \multicolumn{2}{|c|}{ Unemployed } & Other & \multicolumn{2}{|c|}{ Holidays } & Other \\
\hline \multicolumn{2}{|c|}{20.6} & \multicolumn{2}{|c|}{43.5} & 20.6 & \multicolumn{2}{|c|}{8.1} & & 2.0 & 5.1 & 95.9 & & 4.1 \\
\hline
\end{tabular}

Source: Own elaboration.

The sample consists of 400 tourists (60\% male and $40 \%$ female), $27 \%$ of whom are resident in the United Kingdom (U.K.), $18.8 \%$ in Portugal, $11.3 \%$ in Germany and $42.9 \%$ in other locations. The characterisation of respondents, according to the main sociodemographic variables, is presented in Table 1 . Most of the tourists surveyed in this study are male (60\%), live abroad (81.2\%), were visiting the Azores for the first time (68.1\%) and mentioned holidays as their reason for travelling to the Azores (95.9\%). In addition to other variables, the data collection included a set of thirty-two items aimed at ascertaining the main aspects that, in the perception of tourists, should be improved/implemented in the municipality of Ponta Delgada, for which each respondent answered 'Yes' or 'No' (binary or dichotomous variables). The description of these items is shown in Table 2.

Table 2 - Item descriptions: Aspects to improve/implement in the municipality of Ponta Delgada

\begin{tabular}{|l|l|}
\hline \multicolumn{1}{|c|}{ Items } & \multicolumn{1}{c|}{ Items } \\
\hline 1 - Resorts & 17 - Restaurant services: higher quality/more varied food \\
\hline 2 - More spas & 18 - Better tourism planning in the municipality areas \\
\hline 3 - Thalassotherapy & 19 - More/better nature preservation \\
\hline 4 - More cultural spaces & 20 - Better signs on roads and at tourist attractions \\
\hline 5 - More footpaths & 21 - More cultural and tourist entertainment events \\
\hline 6 - More golf courses & 22 - Better beach preservation \\
\hline 7 - More night-time entertainment for young people & 23 - Better preservation of museums and monuments \\
\hline 8 - More night-time entertainment for older people & 24 - Structured routes (e.g., religious, industrial, cultural routes) \\
\hline 9 - More spaces dedicated to local crafts & 25 - Lower prices \\
\hline 10 - More campsites & 26 - Less pollution \\
\hline 11 - Glamping & 27 - More security \\
\hline 12 - Better public transport services & 28 - Better public roads and paths \\
\hline 13 - Better taxi service & 29 - Better conservation of buildings \\
\hline 14 - Better rent-a-car services & 30 - Greater hospitality from locals \\
\hline 15 - Better service in restaurants, shops and bars & 31 - More information in different languages \\
\hline 16 - More nautical tourism services & 32 - Other aspects \\
\hline
\end{tabular}

Source: Own elaboration.

The data were analysed using several statistical methods, such as the chi-square test of independence and some algorithms of Hierarchical Cluster Analysis (HCA).

The chi-square test of independence was used to ascertain those items whose association with the variable 'Means of transport used for travelling to the Azores' is statistically significant.

Cluster Analysis aims to identify groups (clusters) of elements (units of data or variables) to classify, preferably homogeneous and clearly separated. Hierarchical methods, in this context, can be agglomerative or divisive and have the particularity that two given clusters are either disjoined or one is contained within the other. Agglomerative methods were used in this study. It should be noted that HCA, which was applied to identify groups of items (aspects of the municipality of Ponta Delgada) whose responses, regarding the need, or lack thereof, for improvement or implementation, were relatively similar (groups of related items), was carried out on the basis of the Ochiai coefficient and three agglomerative methods, namely Single Linkage, Complete
Linkage and Average Linkage, which can be found in the literature (e.g., Anderberg, 1973). It is also worth mentioning that the Ochiai coefficient considers, in the numerator, the number of cases in which respondents simultaneously answered '1-Yes' to each set of questions/items, $i$ and $j$, with $i, j=1, \ldots, 32$ and $i \neq j$. The selection of the best partitions resulting from HCA was made on the basis of Global Statistics of Levels, STAT (e.g., Lerman, 1970, 1981, 2016; Bacelar-Nicolau, 1987).

\section{Results}

\subsection{Total sample}

For the possible aspects to be improved/implemented in the municipality of Ponta Delgada, only $45.4 \%$ of the total sample were of the opinion that 'nothing needs to be changed (everything is fine)'. Regarding the main aspects which, according to respondents, should be improved or implemented in this municipality, the following deserve a particular mention: '17Restaurant services: Higher quality/more varied food', an aspect 
indicated by $33 \%$ of respondents who selected at least one aspect to be improved (221); '5-More footpaths' (29.4\%); '4-More cultural spaces' (25.8\%); '19-More/better nature preservation' (24.4\%); '20-Better signs on roads and at tourist attractions' (23.5\%); '18-Better tourism planning in the municipality areas'
(21.7\%); '28-Better public roads and paths' (21.7\%); '29-Better conservation of buildings' (21.3\%); '7-More night-time entertainment for young people' (20.8\%); '8-More night-time entertainment for older people' (20.4\%); '2-More spas' (20.4\%); and '25-Lower prices' (20.4\%), according to Figure 1.

\section{Figure 1 - Percentage of respondents who indicated each of the aspects to be improved/implemented in the municipality of Ponta} Delgada

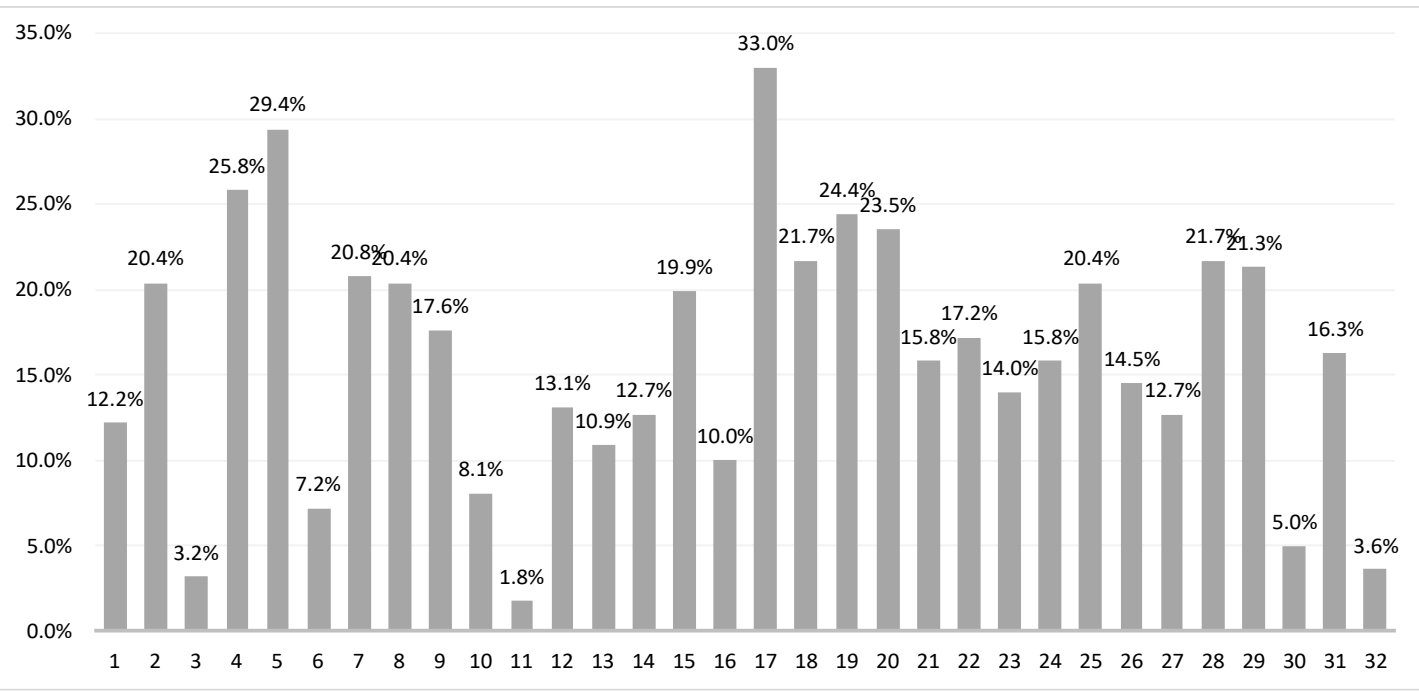

\section{Source: Own elaboration.}

The most frequent answer given to each of the thirty-two items was 'No' (mode), which indicates a feeling of satisfaction on the part of respondents.

Using the chi-square test of independence, statistically significant associations were found between the variable 'Means of transport used for travelling to the Azores' and the following items: 'Resorts' ( $p=0.001)$, 'More golf courses' ( $p=0.007)$, 'More night-time entertainment for young people' $(p=0.000)$, 'More night-time entertainment for older people' $(p=0.000)$, 'More campsites' $(p=0.000)$, 'Better public transport services' ( $p=$ $0.000)$, 'Better taxi service' $(p=0.000)$, 'Better rent-a-car services" $(p=0.000)$, 'Better service in restaurants, shops and bars' ( $p=$ $0.000)$, 'More nautical tourism services' ( $p=0.017)$, 'Restaurant services: higher quality/more varied food' $(p=0.000)$, 'Better tourism planning in the municipality' $(p=0.014)$, 'More/better nature preservation' $(p=0.001)$, 'Better signs on roads and at tourist attractions' $(p=0.001)$, 'Better beach preservation' ( $p=$ $0.000)$, 'Lower prices' $(p=0.008)$, 'Better public roads and paths' $(p=0.032)$, and 'More information in different languages' ( $p=$ 0.007 ). Based on the values of the residuals (a residual is defined as the difference between the observed and expected values of each cell of a contingency table), it was possible to conclude that, in the case of these items, the category 'Yes, needs improving' is associated to the category 'Aeroplane' of the variable 'Means of transport used for travelling to the Azores', which suggests that tourists who travel by aeroplane tend to be more critical.

Regarding the results of the HCA of the items that aim at determining the main aspects to be implemented/improved in the municipality of Ponta Delgada, from the perspective of tourists, according to the Global Statistics of Levels (STAT=12.6471), the best split was the following split into five clusters provided by the Average Linkage criterion (between groups), which was obtained at level 27 of the aggregation process, as can be observed from the dendrogram shown in Figure 2, read from top to bottom:

Cluster 1: $\{1,2,4,5,9,23,8,24,28,29,18,19,17,20,15,21,25$, $31,30,7,13,12,6,14,16,22\}$; Cluster 2: $\{26,27\}$; Cluster 3: $\{3\}$; Cluster 4: $\{10,11\}$; Cluster 5: $\{32\}$.

Cluster 1 contains the following six subclasses:

SC1: $\{1,2,4,5,9,23,8,24\}$, which contains the items that are generally related to tourist attractions, namely resorts, more spas, more cultural spaces, more footpaths, more spaces dedicated to local crafts, better preservation of museums and monuments, more night-time entertainment for older people, and structured routes (e.g., religious, industrial or cultural routes), which can serve as guidance for certain measures to be jointly implemented, with a particular focus on the aspects corresponding to items $2,4,5$ and 8 , which were deemed to require improving by over $20 \%$ of the respondents who chose at least one aspect to be improved;

SC2: $\{28,29\}$, which covers the items relating to better public roads and paths and better conservation of buildings, two of the main aspects pointed out by the respondents, as mentioned in the analysis of the percentages shown in Figure 1. Therefore, these items can be included in a set of measures to be implemented simultaneously. 
SC3: $\{18,19,17,20,15,21\}$, which includes items linked, respectively, to better tourism planning in the different areas of the municipality, more/better nature preservation, restaurant services (higher quality/more variety in food), better signs on roads and at tourist attractions, better service at restaurants, shops and bars, and more cultural and tourist entertainment events. Thus, these aspects may be part of another set of lines of action to be considered in another stage of the strategic planning process, giving priority to the aspects associated with items 18 , 19,17 and 20 , as they are among the most highlighted by tourists;

SC4: $\{25,31,30\}$, which contains the items related to lower prices, more information in different languages, and greater hospitality on the part of locals, with 'Lower prices' (item 25) being the priority aspect of this cluster to implement;
SC5: $\{7,13,12,6,14\}$, which includes items concerning more night-time entertainment for young people, land transport (better taxi, public transport and rent-a-car services), and more golf courses. The most important aspect to be taken into account in this set is the night-time entertainment for young people, as it was selected by $20.8 \%$ of the respondents who pointed out at least one aspect to be improved;

SC6: $\{16,22\}$, which contains the items 'More nautical tourism services' and 'Better beach preservation'. Although these are not among the aspects most mentioned by respondents, they can be part of the same set of measures, as part of a later intervention, after the implementation of more urgent measures, according to the respondents

\section{Figure 2 - Dendrogram: Ochiai coefficient + Average Linkage criterion (between groups)}

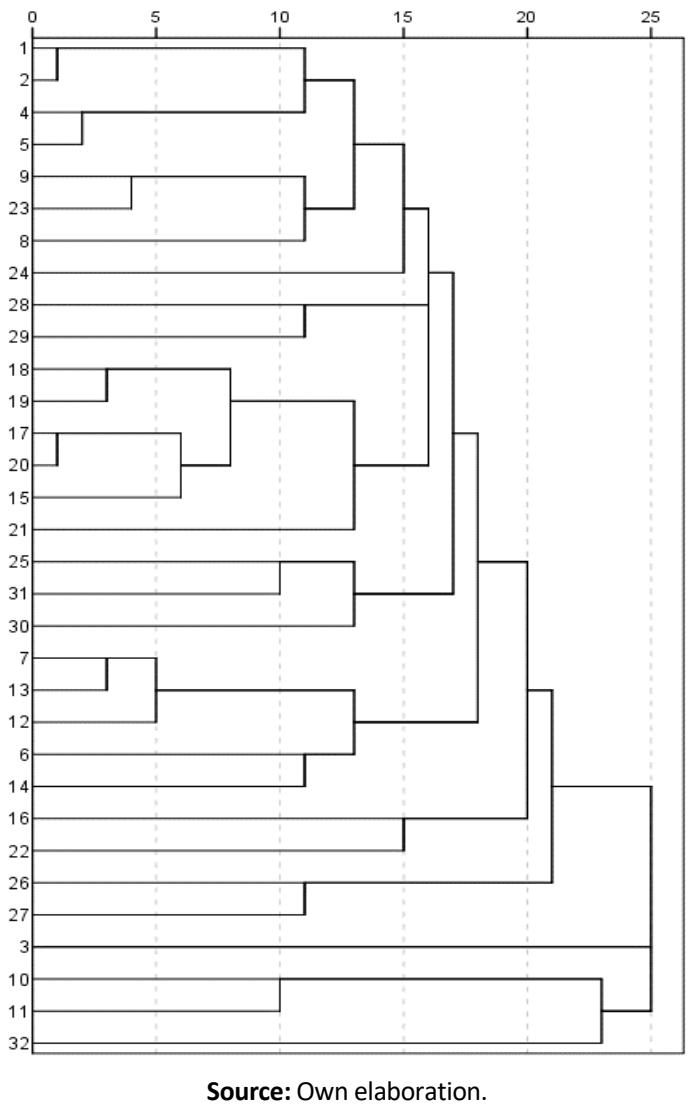

The second cluster contains items 26 ('Less Pollution') and 27 ('More Security'). Of the $12.7 \%$ (28 out of 221 ) who mentioned the need for more security, $35.7 \%$ (10 out of 28 ) mentioned the need for less noise.

The third cluster includes only item 3 ('Thalassotherapy'), which was the item that differed the most from the others in terms of the answers given, so strategic intervention at that level can be done in isolation and not as a priority, since, according to respondents, 'Thalassotherapy' is not among the most important aspects to be implemented.

Cluster 4 contains items 10 ('More Campsites') and 11 ('Glamping'). Of the $1.81 \%$ (4 out of 221) who mentioned the need for improvement on the 'Glamping' offer, 75\% (3 out of 4) mentioned the need for more campsites. Although visitors did not consider these aspects to be the most important, a possible proposal, in the context of tourism planning, for 'Glamping' should be accompanied by a proposal for 'More campsites'.

Cluster 5 contains item 32 ('Other aspects').

\subsection{Considering the sub-samples defined by the variable 'Means} of transport used for travelling to the Azores'

Looking at the sample according to the means of transport used, as shown in Table 3, it can be seen that, of the respondents who travelled by aeroplane, $40.4 \%$ are 34 years old or younger, $40.9 \%$ 
are between 35 and 54 years old, they are mostly foreigners (62.1\%), although $37.9 \%$ are Portuguese, $44.9 \%$ are employed, $18.9 \%$ are self-employed, $12.2 \%$ are students, only $11.2 \%$ are retired, and $8.2 \%$ have travelled for a reason other than holidays. On the other hand, almost half (48.5\%) of the respondents who travelled by boat are over 55 years old, all are foreigners, only $21.4 \%$ are repeat visitors to the Azores, $42.1 \%$ are employed, $22.3 \%$ are self-employed, $29.9 \%$ are retired, and all were travelling for holidays.

Table 3 - Comparison of sociodemographic characteristics of visitors arriving by aeroplane and visitors arriving by boat (\%)

\begin{tabular}{|c|c|c|c|c|c|c|c|c|c|}
\hline & \multicolumn{2}{|c|}{ Gender } & \multicolumn{3}{|c|}{ Age } & \multicolumn{2}{|c|}{ Country } & \multicolumn{2}{|c|}{$1^{\text {st }}$ time in the Azores } \\
\hline & Male & Female & $<=34$ & $35-54$ & $>=55$ & Portugal & Abroad & Yes & No \\
\hline Aeroplane & 57.6 & 42.4 & 40.4 & 40.9 & 18.7 & 37.9 & 62.1 & 57.7 & 42.3 \\
\hline Boat & 62.4 & 37.6 & 12.0 & 39.5 & 48.5 & 0.0 & 100.0 & 78.6 & 21.4 \\
\hline \multicolumn{8}{|c|}{ Employment status } & \multicolumn{2}{|c|}{ Reason for travel } \\
\hline & \multicolumn{2}{|c|}{ Self-employed } & \multicolumn{2}{|c|}{ Employed } & Retired & Student & Unemployed & Holidays & Other \\
\hline Aeroplane & \multicolumn{2}{|c|}{18.9} & \multicolumn{2}{|c|}{44.9} & 11.2 & 12.2 & 2.6 & 91.8 & 8.2 \\
\hline Boat & \multicolumn{2}{|c|}{22.3} & \multicolumn{2}{|c|}{42.1} & 29.9 & 4.1 & 1.5 & 100.0 & 0.0 \\
\hline
\end{tabular}

Source: Own elaboration.

The opinion that 'nothing needs to be changed (everything is fine)' in the municipality of Ponta Delgada was shared by $53.5 \%$ of those who travelled by boat and $36.5 \%$ of those who travelled by aeroplane. It should also be noted that, according to the ChiSquare Test of Independence, there is a statistically significant association between the answer given to this question ('Nothing, everything is fine') and the means of travel to the Azores $(\chi 2=11.118 ; p=0.001)$.

For tourists who travelled by boat and who chose at least one aspect to be improved out of the thirty-two items (valid cases), the main aspects of being improved or implemented are '5-More walking trails', '4-More cultural spaces', and '29-Better conservation of buildings', aspects selected by $36.8 \%, 29.5 \%$ and $29.5 \%$ of these tourists, respectively.

For those who travelled by aeroplane and who chose at least one aspect to be improved (valid cases), the most important aspects to be improved/implemented are: '17-Restaurant services: higher quality/more varied food' (chosen by $49.2 \%$ of these tourists); '7-More night-time entertainment for young people' (34.9\%); '15-Better service in restaurants, shops and bars' (29.4\%); '19-More/better nature preservation' (29.4\%); '20Better signs on roads and at tourist attractions' (28.6\%); '8-More night-time entertainment for older people' (27.8\%); '18-Better tourism planning in the different municipality areas' (24.6\%); '5More footpaths' (23.8\%); '25-Lower prices' (23.8\%); '28-Better public roads and paths' (23.8\%); '4-More cultural spaces' (23.0\%); '22-Better beach preservation' (23.0\%); '12-Better public transport services' (21.4\%); and '14-Better rent-a-car services' (20.6\%). It should also be noted that the mode (the most frequent response) was ' $\mathrm{No}$ ' on all items considered.

For the respondents who travelled by boat, the best partition (STAT=12.0121) of the thirty-two items under analysis was the following partition into eight clusters (level 24), provided by the Average Linkage method (between groups):

Cluster 1: $\{7,10\}$; Cluster 2: $\{3,30\}$; Cluster 3: $\{16,22,21,23,24$, $28,15,17,18,19,20,27,1,2,4,9,5,8,29,31,25,26\}$; Cluster 4:
$\{12\}$; Cluster 5: $\{6\}$; Cluster 6: $\{13,14\}$; Cluster 7: $\{11\}$; Cluster 8: $\{32\}$.

Cluster 1 includes items related to more night-time entertainment for young people and more campsites. Cluster 2 contains the items relating to thalassotherapy and hospitality from locals. Cluster 4 includes one item, the one related to the need for better public transport services. Cluster 5 contains the item related to more golf courses. Cluster 6 covers items related to taxi and rent-a-car services. Cluster 7 only includes item 11 ('Glamping'). Cluster 8 only contains item 32 ('Other aspects'). The remaining items were included in Cluster 3.

For the respondents who travelled by aeroplane, the best partition (STAT=13.6361) was the following partition into seven clusters (level 25), provided by the Average Linkage method (between groups):

Cluster 1: $\{9,23,8,4,25,24,7,13,12,1,2,14,6,28,5,21,18,19$, $17,20,15,31\}$; Cluster 2: $\{16,22\}$; Cluster 3: $\{30\}$; Cluster 4: $\{26$, 27, 29\}; Cluster 5: $\{3\}$; Cluster 6: $\{10,11\}$; Cluster 7: $\{32\}$.

Cluster 2 includes the items related to nautical tourism and beach preservation; Cluster 3 contains the item related to hospitality from locals; Cluster 4 covers three items, respectively, related to less pollution, more security, and better conservation of buildings; Cluster 5 covers one item, related to thalassotherapy; Cluster 6 contains the items related to campsites and glamping; Cluster 7 contains the item 'Other aspects'. All remaining items are included in Cluster 1.

\section{Conclusion}

The results obtained, in relation to the feedback from the visitors who participated in this study, may help the destination's management bodies and other stakeholders to define priorities and lines of action, which aim to implement certain measures that reinforce the quality of the municipality of Ponta Delgada as a tourist destination, and therefore promote greater levels of satisfaction among tourists visiting the Azores. In order to attract tourists, meet their expectations and encourage them to return, it is essential to implement appropriate measures in this context 
and monitor the entire planning process. However, it is important to underline that all the guidelines within the scope of territorial planning and tourism planning and management should advocate the involvement and commitment of all stakeholders, with the aim of promoting the preservation of the natural and cultural heritage, regional development and better interaction between residents and visitors (Couto et al., 2018).

The results of the Hierarchical Cluster Analysis of the items related to various aspects of the municipality of Ponta Delgada allowed us to obtain three typologies of items, respectively, related to the total sample, tourists who travelled by boat, and tourists who travelled by aeroplane. This shows some differences in the views of tourists, especially among those who travelled by different means of transport. Among the main results obtained, it is also worth mentioning the statistically significant relations between the means of transport used to travel to Ponta Delgada and the views about which aspects need to be improved in this municipality. For future research, it is important to study in-depth the factors influencing the association between the category 'Yes, it needs improvement', relating to these items, and the category 'Aeroplane' of the variable 'Means of transport used for travelling to the Azores'. In this sense, it is important to retain some indications from the study carried out by Ponte et al. (2019) regarding the satisfaction levels among tourists visiting Ponta Delgada. On the one hand, tourists travelling by aeroplane tend to be more critical and have lower levels of satisfaction than tourists travelling by boat. On the other hand, the main attractions visited by tourists travelling by boat are generally located in the historical centre of Ponta Delgada and Sete Cidades (one of the most iconic places on the island of São Miguel), while tourists travelling by aeroplane are more likely to visit attractions and carry out activities further away from these places. Similarly, tourists who arrived in the Azores by plane are more critical of the quality of support services, particularly restaurant services. This is not the case among tourists who travel by boat because, in general, they are passengers in cruises, where these services are already included, making it less likely for them to consume at the destination. It will therefore be important to check whether the greater satisfaction of tourists travelling by boat is due to a shorter average stay at the destination. This could mean they have less time to carry out activities, and visit attractions outside the historical centre, use fewer resources, access fewer tourist experiences, have less contact and consume fewer support services.

\section{Acknowledgements}

The authors would like to thank Ponta Delgada's City Hall and Fundo de Maneio for the opportunity to work on this project and thereby develop this article. This paper is financed by Portuguese national funds through FCT - Fundação para a Ciência e a Tecnologia, I.P., project number UIDB/00685/2020.

\section{References}

Anderberg, M. R. (1973). Cluster Analysis for Applications. New York: Academic Press.
Bacelar-Nicolau, H. (1987). On the distribution equivalence in cluster analysis. In P.A. Devijver \& J. Kittler (Eds.), Pattern recognition theory and applications. NATO ASI Series, Series F: Computer and Systems Sciences, vol. 30 (pp. 73-79). Berlin, Heidelberg: Springer - Verlag. https://doi.org/10.1007/978-3-642-83069-3_7

Benckendorff, P., \& Pearce, P. (2003). Australian tourist attractions: The links between organisational characteristics and planning. Journal of Travel Research, 42, 24-35. https://doi.org/10.1177/0047287503253948

Briassoulis, H. (2002). Sustainable tourism and the question of the commons. Annals of Tourism Research, 29(4), 1065-1085. https://doi.org/10.1016/S0160-7383(02)00021-X

Buhalis, D. (2000). Marketing the competitive destination of the future. Tourism Management, 21, 97-116. https://doi.org/10.1016/S02615177(99)00095-3

Couto, G., Pimentel, P., \& Ponte, J. (2017). Tourism development potential in an insular territory: The Case of Ribeira Grande in the Azores. Journal of Tourism Research \& Hospitality, 6(2). https://doi.org/10.4172/23248807.1000166

Couto, G., Pimentel, P., Ponte, J., Oliveira, A., Gonçalves, P., Arruda, A., \& Oliveira, B. (2020). Adventure Tourism in the Azores. Ponta Delgada: Centro de Estudos de Economia Aplicada do Atlântico.

Couto, G., Pimentel, P., Santos, C., Ponte, J., \& Oliveira, A. (2018). Estratégia para o Desenvolvimento Turístico de Ponta Delgada. Ponta Delgada: Centro de Estudos de Economia Aplicada do Atlântico.

Dinica, V. (2009). Governance for sustainable tourism: a comparison of international and Dutch visions. Journal of Sustainable Tourism, 17(5), 583-603. https://doi.org/10.1080/09669580902855836

Fossgard, K., \& Fredman, P. (2019). Dimensions in the nature-based tourism experiencescape: An explorative analysis. Journal of Outdoor $\begin{array}{llll}\text { Recreation and Tourism, 28, } 100219 . & \end{array}$ https://doi.org/10.1016/j.jort.2019.04.001

Hui, T., Wan, D., \& Ho, A. (2007). Tourists' satisfaction, recommendation and revisiting Singapore. Tourism Management, 28(4), 965-975. https://doi.org/10.1016/j.tourman.2006.08.008

Jackman, M., Lorde, T., Lowe, S., \& Alleyne, A. (2011). Evaluating tourism competitiveness of small island developing states: A revealed comparative advantage approach. Anatolia - An International Journal of Tourism and Hospitality Research, 22(3), 350-360. https://doi.org/10.1080/13032917.2011.626311

Kozak, M., \& Baloglu, S. (2011). Managing and marketing tourist destinations: Strategies to gain a competitive edge. New York: Routledge. https://doi.org/10.4324/9780203842300

Lerman, I. C. (1970). Sur l'analyse des données préalable à une classification automatique (Proposition d'une nouvelle mesure de similarité). Rev. Mathématiques et Sciences Humaines, 32(8), 5-15.

Lerman, I.C. (1981). Classification et analyse ordinale des données. Paris: Dunod.

Lerman, I.C. (2016). Foundations and methods in combinatorial and statistical data analysis and clustering. Series: Advanced Information and Knowledge Processing. London: Springer-Verlag.

McMinn, S. (1997). The challenge of sustainable tourism. The Environmentalist, 17, https://doi.org/10.1023/A:1018504117490

Mihalič, T. (2000). Environmental management of a tourist destination: A factor of tourism competitiveness. Tourism Management, 21, 65-78. https://doi.org/10.1016/S0261-5177(99)00096-5

Moniz, A. (2009). A Sustentabilidade do turismo em Ilhas de pequena dimensão: O Caso dos Açores. Ponta Delgada: Centro de Estudos de Economia Aplicada do Atlântico - CEEApIA.

Philips, P., \& Moutinho, L. (2014). Critical review of strategic planning research in hospitality and tourism. Annals of Tourism Research, 48, 96120. https://doi.org/10.1016/j.annals.2014.05.013

Ponte, J. C., Couto, G., Pimentel, P., \& Oliveira, A. (2018). Tourism activities and companies in a sustainable adventure tourism destination: the 
Azores. Tourism \& Management Studies, 14(4), 25-38. https://doi.org/10.18089/tms.2018.14403

Ponte, J., Couto, G., Pimentel, P., Sousa, Á., \& Oliveira, A. (2019). Tourist satisfaction with the Municipality of Ponta Delgada (Azores). GeSec Revista de Gestão e Secretariado, 10(3), 192-2017.

Ponte, J., Couto, G., Pimentel, P., Sousa, Á., \& Oliveira, A. (2020). Municipal tourism planning in an island territory: the case of Ribeira Grande in the Azores. Tourism Planning \& Development. https://doi.org/10.1080/21568316.2020.1816567

Romero, C., Mastronardi, L., Tarelli, J., \& Haslop, F. (2019). The regional impact of tourism when data is scarce. An application to the province of Salta. Tourism Planning \& Development. https://doi.org/10.1080/21568316.2019.1673808

Santos, C., Couto, G., Pimentel, P., \& Vieira, J. (2011). Quality of the Azores destination in the perspective of tourists. Tourism and Hospitality Research, 12 (1), 32-42. https://doi.org/10.1177/1467358411429639

Silva, F. (2017). Planeamento e desenvolvimento turístico. In F. Silva, \& J. Umbelino (Eds.), Planeamento e desenvolvimento turístico. Lisbon: Lidel.

Silva, F., \& Almeida, M.C. (2013). Sustentabilidade do turismo na natureza nos Açores - O caso do canyoning. In M. C. Almeida (Ed.), Turismo e desporto na natureza, 5-19. Estoril, Portugal: Associação de Desportos de Aventura Desnível.

Sukiman, M. F., Omar, S. I., Muhibudin, M., Yussof, I., \& Mohamed, B. (2013). Tourist satisfaction as the key to destination survival in Pahang. Procedia - Social and Behavioral Sciences, 91, 78-87. https://doi.org/10.1016/j.sbspro.2013.08.404

Tseng, S. (2012). A Comparison of overseas destinations and tourist satisfaction: A hybrid graphical representation. Interdisciplinary Journal of Contemporary Research in Business, 4(5), 742-752. Retrieved 16.10.2018 from http://journal-archieves23.webs.com/742-752.pdf

Veiga, C., Santos, M.C., Águas, P., \& Santos, J.A.C. (2018). Tourism as a key driver to address challenges. Worldwide Hospitality and Tourism Themes, 10(6), 662-673. http://dx.doi.org/10.1108/WHATT-08-2018-0054

Vieira, J., Couto, G., Pimentel, P., Menezes, A., Moniz, A., \& Sousa, F. (2013). The satisfaction of the Nordic Tourist with the Azores as destination. Scandinavian Journal of Hospitality and Tourism, 13(1), 5872. http://dx.doi.org/10.1080/15022250.2014.959806 